\title{
PROFESSIONALISM, STAFF COMPETENCY AND FINANCIAL REPORTING QUALITY IN THE PUBLIC SECTOR
}

\author{
MAARUF MUSTAPHA \\ Department of Local Government \& Development Studies \\ Ahmadu Bello University, Zaria, Nigeria \\ mmustaphaphd@gmail.com
}

\begin{abstract}
The financial reporting quality (FRQ) refers to better information dissemination across different users. It is a critical phenomenon for organizations' performance and survival. The public sector in many countries have witnessed considerable changes in the past decades. The prominent one being the international public sector accounting standards (IPSAS) for the public sector entities. Drawing on contingency and institutional theories, this study tests the effects of professionalism on the relationship between staff competency and FRQ under the new accounting standards. Using a survey research approach and self-administered questionnaire, data were gathered from 118 directors of finance representing local governments of four states in the north-west geopolitical zone of Nigeria. The Partial Least Squares Structural Equation Modeling (PLS-SEM) estimate revealed a significant positive relationship between staff competence and FRQ. Conversely, no significant effect was found in the interaction of professionalism on the model. The study implication is discussed in the context of Nigeria.
\end{abstract}

Keywords: Financial reporting quality, Competency, Professionalism, Public sector accounting.

Received: $28 / 2 / 2018$

Revised: 03/5/2018

\section{Introduction}

Financial reporting quality (FRQ) has been described as a pervasive phenomenon and is costly to organizations (Achim, 2014; Gjorgieva-Trajkovska et al., 2017). Better financial reporting quality (FRQ) can translate to lower cost of capital (Armstrong et al. 2010; Legenzova, 2016), increased profitability (Altahat, 2015; Hirst, Hopkins, \& Wahlen, 2004) and is a demonstration of accountability and transparency (Muñoz et al., 2013; Pina et al., 2010). On the other hand, deficiency in FRQ causes substantial losses to organizations and may bring negative and adverse effects on their going concern and consequential liquidation (Martínez-Ferrero, et al., 2013; Tarus et al., 2015).
Accepted: 06/11/2018

Published: 14/7/2019
Generally acceptable conceptualization of what FRQ involves has been a subject of wide debate and an elusive phenomenon among scholars. However, general inferences from accounting theories depict that the value of financial reports lie in the ability of financial statements to provide accurate and fair information about the underlying financial position and economic performance of an entity (Herath \& Albarqi, 2017). In addition, the significance of quality financial reporting lies in the effectiveness of information dissemination across different users (Bukenya, 2014; Ştefănescu, 2013), its decision usefulness (Cuong \& Ly, 2017) and the essence of reporting what it purports to reveal (Hope, 2003). 
However, the realization of the essence of FRQ among public sector organizations has witnessed dramatic changes among countries worldwide in the last 30 years or so (Laswad \& Redmayne, 2015). One significant change in the recent time is the introduction of the international public sector accounting standards (IPSAS). IPSAS is a global initiative brought by the New Public Management (NPM) phenomena (Massey, 1999; Nobe, 2015). It is the public sector version of the International Financial Reporting Standards (IFRS) which uses accrual accounting as opposed to cash accounting basis. The shift towards using IPSAS in the public sector has the potential to radically change the practice of accounting and financial reporting in the public sector towards enhancing high quality financial reporting (ACCA, 2017).

Following the global financial crisis, governments around the world have heightened the need for greater transparency and accountability in their operations (ACCA, 2017; Akhidime, 2012). Thus, the adoption of IPSAS is gaining momentum across the world, because the traditional cash-based financial statements were less able to predict and prevent sovereign liquidity crises (Lin et al., 2015; Linsmeier, 2011). In order to attract foreign direct investments, countries have initiated financial management reform programs, including the adoption of IPSAS as part of a broader reform programs of the public sector.

However, despite the elaborate progress made so far regarding the adoption of IPSAS, the results of its implementation to accentuate FRQ among constituencies still leaves much to be desired (ACCA, 2017). Accordingly, the Association of Chartered Certified Accountants (ACCA, 2017) reveals that, specific, complex and consistent implementation challenges facing the IPSAS adopting countries is a cause for concern. For instance, the report of ACCA (2017) among others revealed that, staff competence has been a challenging factor hindering the achievement of effective implementation of IPSAS in many countries.
Nonetheless, within the context of developing countries, the cash-basis IPSAS has been widely adopted. Chan (2008) argued that the cash-basis IPSAS would likely become de facto IPSAS and preferred reporting style for public organizations in developing countries in the future, due to its simplicity and lesser cost implication. Specifically, Nigeria is one of the developing countries which adopted the cash-basis IPSAS since 2014 across its three tiers of government, as an initial step prior to transition to the accrualbased IPSAS.

In this regard, extant studies that have researched into the adoption of the accounting standard relating to Nigeria have identified some challenges which impede successful implementation of the reform in the public sector. These include lack of developed legal and regulatory framework (Maigoshi, 2014), low level of awareness among participants (e.g. preparers, users, investors etc.) (Madawaki, 2014), shortage of skilled and competent staff (Garuba \& Donwa, 2011; Musa, 2015), and absence of institutions for education and professional capacity building for practitioners and managers (Herbert et al., 2014).

However, despite the noteworthiness of these studies, the analysis of the identified challenges have been only descriptive of the issues without empirical evidence. In addition, while there have been no clear inferences made by previous studies to evaluate specific or compound effect of these challenges to FRQ, the dearth of empirical research that investigates how these factors affect the elaboration of quality financial reporting is obvious.

Therefore, the objective of this paper is to carry out a study on local governments, which examines the perceived role of staff competency on FRQ after the adoption of the cash-basis IPSAS in Nigeria. A comprehensive literature review relating to other contexts have shown that, the relationship between staff competence and FRQ has been somewhat mixed. Hence, the 
need for more studies becomes imperative. In addition, this study incorporates professionalism as a moderator variable.

Although the term competence is most frequently cited as a synonym for professionalism, inferences from extant literature had drawn a thin divide between the concepts (e.g. Muzio et al., 2013; Svensson, 2006). While professionalism involves a specialized capabilities and training by designated institutions, competence involves the acquisition of basic capabilities to perform a job (Kasim, 2015).

Moreover, prior studies have established that the term professionalism is a noteworthy explanatory construct which associate positively with FRQ under accounting reforms environment (Darwanis et al., 2016; Khumawala, Marlowe, \& Neely, 2014; Ninlaphay \& Ussahawanitchakit, 2011). Thus, this paper theorizes to understand whether professionalism matters in strengthening the relationship between competency and FRQ after the adoption of international accounting standard. To achieve the above objectives, a questionnaire survey was administered on directors of finance of local governments, based on the understanding that they are competent stakeholders with the required knowledge and experience on local government accounting system and operations.

\section{Financial Reporting Quality}

FRQ is a concept derived from financial reporting system of economic entities. The term is widely used in financial accounting literature (Bageva, 2010) and different definitions have been suggested. For instance, Jonas and Blanchet (2000), states "quality financial reporting involves full and transparent financial information that is not designed to obfuscate or mislead users". Lin et al. (2015) defines FRQ as the degree to which financial statements reveal true and fair information about performance of the financial position of an entity.
Methods such as accrual accounting models (Van Tendeloo \& Vanstraelen, 2005), value relevance models (Barth et al., 2001, Maines \& Wahlen, 2006), and those focusing on specific elements of the annual report (Hirst et al., 2004) have often been used to measure FRQ in the private sector. While in the public sector, FRQ is measured largely through the operationalization of the qualitative characteristics of the financial statements (Braam \& Beest, 2013; McDaniel et al., 2002). Concepts such as relevance, faithful representation, understandability, comparability and timeliness are considered as potential qualitative factors that describes FRQ (Cohen, Kaimenakis, \& Venieris, 2013; IFAC International Federation of Accountants \& IFAC, 2015; Jonas \& Blanchet, 2000).

In the public sector, the evolution and development of the international public sector accounting standards (IPSAS) has necessitated the establishment of a conceptual framework that are public sector specific. Though, the structure of the conceptual framework (CF) is similar with that of the private sector (Rutherford, 1992). For instance, a common feature of frameworks is, first, the proposition that information provided to users of financial reports should be useful. Thus, the public sector frame concentrates on what is called general purpose financial reporting (GPFR). The qualitative characteristics of information included in GPFRs of public sector entities are relevance, faithful representation, understandability, timeliness, comparability, and verifiability. The framework of IASB (2010), IFAC (2009), refers to the qualitative attributes of relevance and faithful representation as the fundamental qualitative characteristics underlying usefulness of information for users' decision making. Thus, this paper focuses on two sets of qualitative characteristics, namely, relevance and faithful representation.

Exposure Draft (ED) by the International Federation of Accountant (IFAC, 2009) indicates that information would be relevant 
makes a difference in the user's decisions making concerning an economic phenomenon. For an accounting information to be faithfully represented, financial report must have reflective feature of the annual report which is complete, neutral and free from material error.

Based on the above, the present paper adopts relevance and faithful representation as dimensions to measure FRQ. Relevance is measured on items that determines (1) the entity's ability to generate information about future operation and/or economic activities and (2) whether the annual reports provide information about past operations and/or economic activities about the entity. On the other hand, items measuring faithful representation determine (3) the ability of financial reports to be presented in a comprehensive and transparent manner and (4) whether the annual reports present information regarding positive and/or negative financial events of the entity. However, the four items used to operationalized the two dimension of relevance and faithful representation have been adapted from the study of Barth et al. (2001), Deans (2007), Jonas and Blanchet (2000), McDaniel et al. (2002).

\section{Hypothesis Development}

\section{Staff Competence}

Competence is a term usually utilized in the realm of human resource management and its exact conceptualization has been widely debated in the literature. Kasim (2015) states: "competence is what people need to know and be able to do to perform their job effectively". According to Dingle (1995), competence is a combination of knowledge, skills and awareness. To avoid ambiguity, Dingle (1995) clarifies that knowledge refers to the understanding of fundamental principles required to accomplish the task at hand, while skills involve the application of this understanding. Meanwhile, awareness refers to the proper application of skills (for example in accordance with professional and corporate "good practice").

Theoretically, the significant exigencies of contingency theory implicitly reveals competency as an endogenous organizational factor that influences organizational performance outcome. Lüder (1992), explored the application of contingency theory to explain the underlying organizational contingencies and their effect on organization's performance. The imperative of the theory examined the diffusion of more innovation in the information system of public sector accounting and the resultant effect on reporting outcome (Chan, Jones, \& Lüder, 1996; Lüder, 1992). The contextual frame of Luder's contingency model, adopts four variables including implementation barriers which significantly affects organizational performance. Within the framework, implementation barrier involves the militating organizational factors which if not ameliorated may impede effective organizational performance (Chan et al., 1996). Based on this theoretical stand, poor competence of staff is described as 'implementation barrier' that may impede the achievement of implementation of accounting standards and subsequently, quality of accounting reporting (Ball et al., 2003).

Scores of research on accounting have adopted the concept of competency as a factor to test accounting reporting outcomes. Findings from these studies are inconclusive as they revealed mixed findings. For instance, Dwyer and Wilson (1989) examines managers competency and financial reporting quality in terms of timely accounting reporting. The findings reveal that managers with the required educational qualification produces timely financial report in terms of reduced time lag between fiscal year end and the auditor's report date. Next, Nur Afiah and Rahmatika (2014) investigate the influence of competence and internal control on 
the quality of of financial reporting and its implications on good governance. The study finds that staff competency has a significant effect on the quality of financial reporting. Similarly, Setiyawati (2013) shows internal accountants' competence has a significant effects on the quality of financial reporting. This result was reinforced by Saputra and Hutahaean (2016), who show that competence of accountants had a positive influence on the quality of the evaluation report formed.

Consistent with the above, Abbott et al. (2016) test the quality of internal audit on financial reporting quality, and finds competence to be a necessary antecedent of effective internal audit functions and financial reporting quality. In a recent study, Puncreobutr et al. (2017) show that accountants' competence of SMEs has a significant positive association with quality of financial reports of SMEs in Indonesia.

Conversely, an inverse association between competence and FRQ was also documented. For example, Kasim (2015) finds that characteristics of competence possessed by the staff has no significant effect on financial reporting quality. The insignificance effect of the relationship was blamed on the lack of sound accounting knowledge by the staff handling the preparation of the financial reports. This finding supports earlier studies by Cheng et al. (2002), and $\mathrm{Xu}$ et al. (2003). Similarly, Darwanis et al. (2016), in their study in Indonesia find that staff competency is not significant in influencing FRQ.

Overall, the review of literature above on the influence of staff competence on financial reporting quality reveals mixed findings. However, consequential expectation posits that higher staff competency should lead to increased quality of financial reporting. In view of this argument, the following hypothesis is advanced:

Hypothesis 1: Staff competency is positively associated with financial reporting quality.

\section{Professionalism as a Moderator}

Professionalism is a multidimensional concept. It means different things in different situations and to different people (Evetts, 2013). Professionalism involves a specialized technical skills and good judgment expected from a person who is trained to do a job (Evetts, 2011). According to the Association of professional Enginneer, geologists and geophysicists (APEGGA, 2004), a professional is a calling, requiring specialized knowledge, skills and methods underlie by scientific and scholarly principles. This suggest that professionalism has an edge over competence required to perform a specific task (skill, ability and knowledge). While the former requires a specialized capabilities and training by designated institution the later involves the acquisition of basic capabilities to perform a job.

In the realm of accounting, professionalism is the role of accounting that demonstrates responsibility for the performance of the business professional (Staubus, 2004). In other words, accounting professionalism is the performance of accounting with knowledge, understanding, virtue and ethics, and follows the rule and regulations. Based on its nature, the concept of professionalism in previous studies was referred to as involving accountability, transparency, ethical practice, communication, or specialized skills (Darwanis et al., 2016).

The essence of professionalism in the application of accounting principles and practices has a direct relationship with the quality of financial reporting in terms of reliability (Mataira \& Van Peursem, 2010), business reputation (Ninlaphay \& Ussahawanitchakit, 2011) and support future data accuracy leading to information useful for decision-making (Moehrle et al., 2009). Research have established that professionalism is positively related to FRQ. For example, professionalism has been linked with disclosure quality in governmental financial report (Robbins \& Austin, 1986), and accounting standards (Christiaens, 1999). Ninlaphay 
and Ussahawanitchakit (2011) show that accounting professionalism have a significant positive effect on financial reporting quality, and financial reporting quality has a significant positive association with information usefulness. Similarly, Bakhtiar and Azimifar (2013) finds that professional ethics in accounting profession lead to quality of financial reporting.

Based on the discussion, the following hypothesis is advanced:

Hypothesis 2: Professionalism is positively associated with financial reporting quality.

Furthermore, given the inconsistent findings in the literature regarding the staff competency/FRQ relations, this paper incorporates professionalism as a moderating variable to strengthen the relationship between staff competence and FRQ. This paper argues that professionalism could increase the competence of staff to implement improved accounting practices (e.g. adoption of cash-basis IPSAS) to produce quality financial reports. This argument is drawn from both empirical and theoretical evidence.

First, Khumawala et al. (2014) finds the level of professional technical attainment has a predictive influence on improved support to enhance the competence of staff. This suggests a significant positive relationship between the complementary role of professional support in the work place and improved staff competence. This is demonstrated through development and support for professional proficiency in skills and ethics, including engagement in norms of best practice of professional institutions.

Second, theoretical lessons drawn from institutional normative isomorphic theory (DiMaggio \& Powell, 1991) is relevant to the current global accounting reform towards the standardization of accounting reporting and practices. This theory posits that professionalism has a predictive influence and stimulation for adoption of international accounting standards and consequent improvement in FRQ. Based on this, theorists have argued that, educational attainment which is fundamental to development of competence (Espositi et al., 2015; Kasim, 2015) positively relates to professionalism as a fundamental requirement leading to specialized capabilities (Judge et al., 2010). This professional capability is induced by the requirement and motivations of the fundamentals of normative institutional pressure which is instilled in organizations. This means, due to internationalization and standardization of accounting practice, normative institutional pressure on organizations allows for the institution of professional competencies to accentuate better application of the reform.

Consequently, based on the review of extant literature and theoretical justifications, professionalism being an explanatory and equally antecedent variable to both factors of organizational contingency (accountant competency) and FRQ, could serve as a viable institutional factor to strengthen the relationship between accountant competency and FRQ. Therefore, the following hypothesis is tested.

Hypothesis 3: Professionalism strengthens the relationship between staff competence and $F R Q$

\section{Methods}

\section{Population and Sample Size}

The population of the study is all local governments located in the seven northwestern part of Nigeria, which amounts to 185 local governments as shown on Table.

This region is selected because of the existence of relative peace and security in the zone which allow the researcher to safely access data. Out of the seven states, this study focuses on only four states (Kaduna, Kano, Katsina \& Sokoto) which brought the sample size to 124 local governments. The states are chosen because they are the older ones within the zone and it is expected that they have a well-established system and structure of 
local government administration compared to the others. Generalization may be inferred from the results of the findings because accounting principles in the Nigerian local government system are homogenous among the councils (Bello-Imam, 2007).

Accordingly, the subjects consist of 124 directors of finance of the respective local governments under study. Directors of finance were selected as subjects based on the understanding that they possess the required knowledge and experience about local government accounting and operations. This understanding is consistent with the views of Larcker and Lessig (1980) that argues that managers (preparers) possess sufficient insight based on their decision process to specify information they consider useful. This size is sufficient and consistent with Krejcie and Morgan (1970) population-sample determining table and Roscoe's (1975) rule of thumb.

Table 1

State and Local Government in the Northwestern Zones of Nigeria

\begin{tabular}{lllllllll}
\hline State & Jigawa & Kaduna & Kano & Katsina & Kebbi & Sokoto & Zamfara & Total \\
\hline LG & 26 & 23 & 44 & 34 & 21 & 23 & 14 & 185 \\
\hline
\end{tabular}

\section{Data Collection}

This study adopted a structured selfadministered questionnaire consisting of closeended questions. A multi-scale choice questions involving seven-point Likert, dichotomous, categorical and numeric scale were used for scaling. Prior to the administration of the actual survey, an initial draft of the questionnaire was pre-tested to forestall any ambiguities that have not been observed by the researcher. As such, five experts were identified and engaged to examine the draft questionnaire for its face validity in terms of wording, applicability, clarity, simplicity and ambiguity of the items (Dillman, 1991; Yaghmale, 2009) and content validity (Lawshe, 1975). Out of 16 original items in the questionnaire, 13 were retained as shown on Table 2.

Table 2

Results of Retained Items for Content Validity Test

\begin{tabular}{lllcc}
\hline S/N & Variable & Code & $\begin{array}{c}\text { Original No. of } \\
\text { Item }\end{array}$ & Items Retained \\
\hline 1 & Financial Reporting Quality & FRQ & 6 & 4 \\
2 & Staff Competence & COM & 5 & 4 \\
3 & Professionalism & PFR & 5 & 5 \\
\hline
\end{tabular}

Consequently, out of the total 124 questionnaires distributed, 118 (95\%) were completed and returned. Table 3 outlines the demographic profile of the finance directors. Of the 118 respondents, $78(66 \%)$ were male. Most of the participants' age ranged between 41 to 50 years. Regarding 
job experience, about $70 \%$ of the respondents have well above 10 years experience with almost $90 \%$ having educational qualification of at least a
Bachelor degree or its equivalent (higher national diploma). Only $20 \%$ of them has a professional qualification.

Table 3

Profile of Respondents

\begin{tabular}{lcc}
\hline & No. of respondents & Percentage \\
\hline Gender & 78 & 66.1 \\
Male & 40 & 33.9 \\
Female & & \\
Age group & 97 & 82.2 \\
$41-50$ years & 21 & 17.8 \\
$51-60$ years & & \\
Experience & 40 & 33.9 \\
5-10 years & 78 & 66.1 \\
10 years and above & & \\
Educational qualification & 16 & 13.6 \\
Master's & 102 & 86.4 \\
Bachelor/HND & & 20.3 \\
Professional qualification & 24 & 79.7 \\
Yes & 94 & \\
No & & \\
\hline
\end{tabular}

\section{Measurements}

Details of the questions that measure FRQ (4 items), competency (COM) (4 items) and professionalism (PRF) (5 items) are depicted in the appendix. The measurement for FRQ were adopted from the study of Bartov et al. (2005), Jonas and Blanchet (2000), and McDaniel et al. (2002). In measuring FRQ, respondents were asked to state their perception on a 7-point scale statements, ranging from "1" (very low) to "7" (very high) on statements such as "The annual financial report concerning your local government discloses information about future operation and/ or future economic activities of the council". Four items were adopted from the study of Kak et al. (2001) to measure accountants' competency (COM) based on a 7-point scale ranging from "1" "strongly disagree" to "7" "strongly agree". Professionalism was measured based on the studies of Christiaens (1999), Khumawala et al. (2014), Robbins and Austin (1986). Items used were rated on a 7-point scale ranging from "1" "strongly disagree" to "7" "strongly agree". A sample of the items which participants were asked regarding PRF include: "The membership of the professional accounting institutes helps in the implementation of the cash-basis IPSAS in your local government". 


\section{Results and Discussion}

Partial least square structural equation modeling (PLS-SEM) was used to analyse the data. The analysis was performed using smart PLS 3.0 software. The PLS path modeling is considered the most suitable technique in this study for important reasons. First, PLS path modeling allows for the simultaneous estimation of the relationship between constructs (structural model) and the relationship between indicators including their corresponding latent constructs (measurement model) (Willaby et al., 2015). Second, PLS is suitable and ideal for measuring predictive models (Hair et al., 2014). Before conducting the analysis, the raw data were screened to ensure that key assumption guiding multivariate analysis and PLS SEM statistical tool such as test of linearity and normality were not violated (Hair et al., 2014).

\section{Result of PLS-SEM Path Model}

Testing the PLS-SEM path model involves two processes (Jörg Henseler, Ringle, \& Sarstedt, 2015), that is, testing the measurement model and the structural model. The measurement model, also known as the outer model, explains the relationships between indicators and their respective latent variables (Hair et al., 2014). Therefore, to assess the reliability and validity of the scales adopted in this study, individual item reliability, internal consistency reliability, and discriminant validity were ascertained. Results of the factor loading and reliability are presented in Table 4. According to Hair et al. (2014), the reliability of individual item is confirmed when its standardized loading is 0.707 and above. One item (PFR 02) whose loading was lower than 0.7 was deleted, reducing the items from 13 to 12 .

Table 4

Factor Loading and Reliability

\begin{tabular}{llllll}
\hline Latent variables & Items & $\begin{array}{l}\text { Standardized } \\
\text { Loadings }\end{array}$ & Alpha & $\begin{array}{l}\text { Composite } \\
\text { Reliability }\end{array}$ & AVE \\
\hline Financial reporting & FRQ01 & 0.847 & 0.928 & 0.931 & 0.823 \\
quality & FRQ02 & 0.902 & & & \\
& FRQ03 & 0.936 & & & \\
& FRQ04 & 0.940 & & & \\
& & & & \\
Staff competence & COM01 & 0.921 & 0.904 & 0.933 & \\
& COM02 & 0.896 & & & \\
& COM03 & 0.902 & & & \\
& COM04 & 0.806 & & & \\
& & & & & \\
& & & & \\
& PRF01 & 0.896 & 0.762 & \\
\hline
\end{tabular}


The internal consistency was estimated using composite reliability coefficient of the measure. It is deemed adequate because the score is greater than 0.7 (Hair et al., 2011). Next, the convergent validity was ascertained using the average variance extracted (AVE) ( Fornell \& Larcker, 1981; Henseler et al., 2016). The AVE result shows that the convergent validity is satisfied because they are greater than 0.5
(Fornell \& Larcker, 1981). Fourthly, to ascertain the discriminant validity, the approach suggested by Fornell and Larcker (1981) was adopted. Based on the recommendation by Fornell and Larcker (1981), this study reports adequate discriminant validity, because as shown in Table 5 , the values of the square root of AVEs (values appear in bold) were greater than the correlations between the constructs.

Table 5

Result of Discriminant Validity

\begin{tabular}{llll}
\hline Latent Constructs & $\mathbf{1}$ & $\mathbf{2}$ & $\mathbf{3}$ \\
\hline 1. Staff Competence & $\mathbf{0 . 8 8 2}$ & & \\
2. Financial Reporting Quality & 0.801 & $\mathbf{0 . 9 0 7}$ & \\
3. Professionalism & 0.055 & -0.07 & $\mathbf{0 . 8 7 3}$ \\
\hline
\end{tabular}

The following Table 6 and Figure 1 present the significant path coefficient for this study.

Table 6

Path Coefficient Result

\begin{tabular}{lllllllll}
\hline Hypotheses & Relations & Beta & $\begin{array}{l}\text { Sd. } \\
\text { Error }\end{array}$ & t-value & p-value & Finding & $\mathbf{R}^{2}$ & $\mathbf{Q}^{2}$ \\
\hline H1 & COM $\longrightarrow$ FRQ & 0.812 & 0.039 & 20.903 & $0.000^{* * *}$ & Supported & & \\
H2 & PRF $\longrightarrow$ FRQ & -0.108 & 0.072 & 1.661 & $0.097^{* * * *}$ & Not supported & & \\
H3 & COM x PRF $\longrightarrow$ FRQ & 0.054 & 0.065 & 0.847 & $0.397^{* * *}$ & Not supported & 0.649 & 0.498 \\
\hline
\end{tabular}

Note: Dependent variable: Financial Reporting Quality

*Significant at 0.05 (two-tailed), **Significant at 0.01 (two-tailed), ***Significant at 0.1 (two-tailed)

As shown in Figure 1, the values shown near the arrows represent the t-values. These suggests that the relationship was significant at one-tailed test 0.05 level with critical $t$-value of \pm 1.645 . However, based on the hypotheses stated in this paper, HI predicts that staff competency relates to perceived FRQ. The result in Table 4 reveals that staff competence had a significant positive relationship with financial reporting quality after the application of international accounting standards $(\beta=0.812$, $\mathrm{t}$-value $=20.903$ and $p$-value $<0.01$ ). Thus, HI is supported. Similarly, the direct effect of professionalism was examined on FRQ. Based on the result in Table 6, professionalism shows insignificant relationship with FRQ $(\beta=-0.108$, $\mathrm{t}$-value $=1.661, \mathrm{P}$-value $<$ 0.1 ) suggesting that $\mathrm{H} 2$ is not supported. 


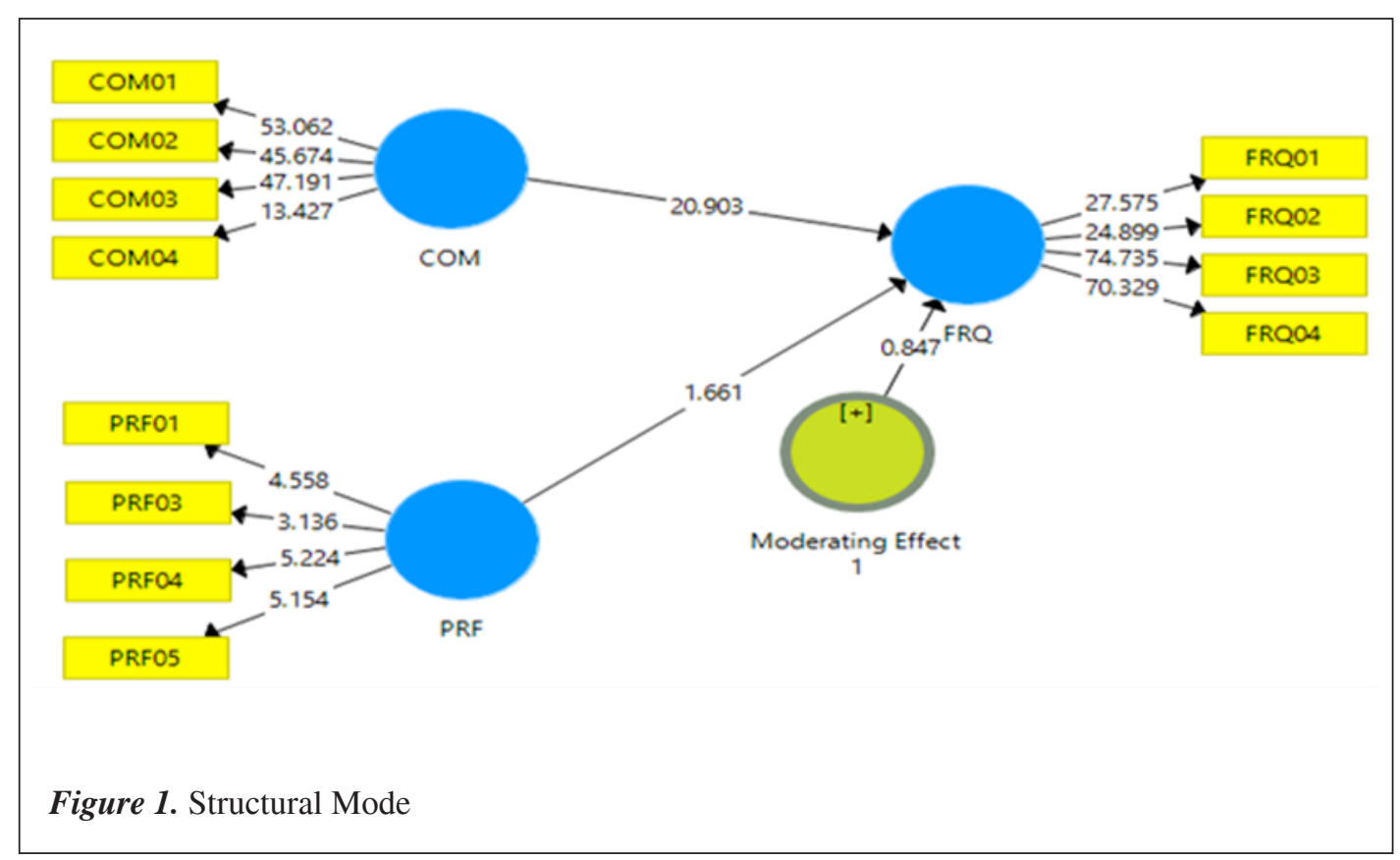

Note $:$ FRQ = financial reporting quality; $\mathrm{COM}=$ staff competence PRF = Professionalism

After ascertaining the significance of the path coefficient for the main model, next, this study assesses the structural model based on two criteria, including the $\mathrm{R}$-squared values and predictive relevance of the study model. The R-squared presents the combined effect of exogenous variables on endogenous variable(s). As shown in Table 4, the value of the R-squared stood at 0.649 , suggesting that the two exogenous latent variables (i.e. competence and professionalism) collectively explained $64.9 \%$ of the variance in financial reporting quality after the adoption of the international accounting standards.

As proposed by Falk and Miller (1992), an $\mathrm{R}$-squared value of 0.10 is an acceptable minimum value of predictive accuracy of determination score between exogenous and the endogenous variable(s). Therefore, it can be substantiated that the endogenous latent variable (FRQ) possesses the acceptable level of R-squared. Lastly, the predictive relevance $\left(\mathrm{Q}^{2}\right)$ of this study was calculated through blindfolding procedure in PLS 3.0 and assessed using the recommendation by Geisser (1974) and Stone (1974). The $\mathrm{Q}^{2}$ is a criterion to measure how well a model predicts the data of omitted cases (Hair et al., 2014). According to Hensele, Ringle and Sinkovics (2009), a research model with $\mathrm{Q}^{2}$ value greater than zero is considered to have predictive relevance. The result of this study shows a $\mathrm{Q}^{2}$ of 0.498 for the endogenous latent variable, suggesting that the model possesses a good predictive relevance.

\section{Moderating Effect}

The moderating effect hypothesis (H3) was tested using Henseler and Chin (2010) product indicator approach. This approach allows the PLS-SEM procedure to detect and estimate the strength of the moderating effect of professionalism on the relationship between staff competence and financial reporting quality (Henseler \& Chin, 2010). Based on the interaction analysis of the moderating variable and the other latent variable, the results in Table 6 and Figure 1 indicate that the items representing professionalism and staff 
competence towards predicting FRQ outcome $(\beta=0.054, \mathrm{t}$-value $=0.847$, P-value $>0.1)$ was statistically insignificant. This therefore indicates that, the moderating effect of professionalism on the relationship between staff competence and FRQ was not supported.

\section{Discussion}

The primary objective of this study was to examine the interaction effect of professionalism on the relationship between staff competence and FRQ following application of the cash-basis IPSAS. This study finds a significant and positive relationship between staff competence and FRQ, and thus supports Hypothesis 1. This suggests that, staff competence in terms knowledge, skills and experience has a significant positive effect on the quality of accounting reports. The educational profile of respondents for the survey testify to the result. According to the demographic profile of respondents (Table 1), over $85 \%$ of the respondents possessed first degree and a considerable number possessed a Master degree. This result is consistent with the study of Dwyer and Wilson (1989) who reported a significant and positive relationship between managers' level of education and financial reporting quality. Similar result was also reported by Nur Afiah and Rahmatika (2014) and Saputra and Hutahaean (2016).

Next, this study hypothesizes that professionalism is significantly related to perceived FRQ. The result of the path model shows that there is no significant relationship between professionalism and FRQ. This indicates that, there is insignificant consideration for application of issues of professionalism in the financial reporting practices among the local governments. Moreover, the statistical result of the proposed hypothesis (H2) based on two-tailed test explain the result of weak/poor motivation for the institution of professionalism in the accounting practice of the local government under study.
This result is contrary to previous studies such as Christiaens (1999), Khumawala et al (2014), Ninlaphay and Ussahawanitchakit (2011) that revealed a significant positive relationship between professionalism and FRQ.

The plausible explanation for the above result suggests there exist a low level of staff development in professional capabilities (e.g. engagement of external professional consultancy, membership of professional institutions, conformity with professional ethics etc.). To illustrate, out of the 118 directors of finance surveyed, only about $20 \%$ possess professional qualification in accounting institutions (e.g. The Institute of Chartered Accountants of Nigeria (ICAN) and The Association of National Accountants of Nigeria (ANAN)). In addition, with regards to engaging the services of external professional consultants in the implementation of the new accounting standards (IPSAS), the mean score indicates a weak performance of the local governments in this direction (mean score $=3.667$, $\min$ score $=1$ and $\max =7$ ).

In addition, studies on local governments in Nigeria have shown there exist poor staff welfare and remuneration package across the local governments (Emerole \& Enyioko, 2015; Okereke \& Daniel, 2010; Okey \& Okechukwu, 2013). This causes brain drain in the civil service of the local governments where the existing professionals mostly transfer their services to some more lucrative sectors to acquire better condition of service. According to Onyishi, Eme and Emeh (2012), the dearth of experienced, technical and professional staff (including accountants) witnessed in the Nigerian local governments is caused by the low image of the local governments in the minds of the professionals, who cannot withstand the poor working condition. Again, due to poor financial incentives and working condition, collaborations between professional external consultants and the local governments through personnel training and consultancy services hardly work. 
Furthermore, Hypothesis 3 is based on the conjecture that professionalism would strengthen the relationship between staff competence and FRQ. As shown in Table 4, professionalism does not interact significantly with the relationship between staff competence and FRQ $(\beta=0.054$, $t$-value $=0.847, \mathrm{P}$-value $>0.1)$. Thus, the possible explanation for the insignificant moderating effects in the model, reveals the poor consideration for professionalism necessary to influence the competency of staff to have significant effect for quality financial reporting in the context of the study.

\section{Conclusion}

Overall, the findings of this study bring significant implications for theory and practice. First, additional empirical evidence has been provided in this study, particularly in the area of organizational contingency and financial reporting quality (Chan, 1994; Lüder, 1992; Upping \& Oliver, 2011), which indicates that, despite the application of accounting standards, there are other organization factors that also interact to affect the quality of reporting outcomes. This area adds to extend the literature on financial reporting, that staff competence is an important organizational contingency that needs to be considered to enhance FRQ while adopting international accounting standards in the public sector.

Second, instead of focusing on the direct relationship, which had shown inconclusive results by previous studies, this study introduced a moderating variable (professionalism) to test the relationship between the explanatory variable (competence) and the explained variable (FRQ). The insignificant moderating effect of professionalism signals the need to adopt caution in the use of institutional factors (e.g. professionalism), particularly in the context that shares similar demographic profile in respect of staff professional support, as evidenced in this study.
Furthermore, the insignificant moderating effect of professionalism on the relationship between staff competence and financial reporting quality, may suggest the need for another moderating variable. Future studies may adopt other institutional factors such the influence of political factors. According to Burns and Scapens (2000), politics play a key role in driving and shaping change processes, and they argued that the exigencies of politics is a critical tool for organizational participants or constituencies (governments, firms, preparer, investors, voters etc.) to adopt as an advantages to satisfy some vested interest over others. This is imperative, particularly as the global initiative in the public sector drives towards changes to internationalization of accounting practice and reporting. The imperatives and consequences of political pressure in the organizational settings have been observed to influence financial reporting outcomes (Bushman \& Piotroski, 2006; Giroux, 1989; Zimmerman, 1977).

Moreover, this study may need to be replicated in different settings and context, using different sample and methods to further validate the revealed findings. Again, a longitudinal research design approach may be explored in future research, to detect and provide insights into changes over time. This may serve as an advantage over the present study that adopted a cross-sectional design, with causal inferences could not be made to the population. Further, FRQ has been measured in the present study through a self-reported measure. While the use of self-report measures as been accused of the problem of common method variance (CMV) and social desirability bias (Podsakoff \& Organ, 1986), these challenges have been ameliorated in this study through several procedural remedies suggested by Podsakoff and Organ (1986). Notwithstanding these, previous studies have supported the validity of the use of self-reported measure to test qualitative attributes of FRQ (e.g. Braam \& Beest, 2013; Jonas \& Blanchet, 2000; Mbobo \& Ekpo, 2016). 
Despite its limitations, this study is able to reveal that staff competency significantly and positively influences perceived FRQ, while the moderating effect of professionalism between the relationships was inconsequential. These results however, underscore the importance of staff competence as an important organizational factor to be considered in ensuring quality financial reporting while applying international accounting standards. The findings also demonstrate the paucity of institution of professionalism in the area under consideration. Furthermore, this study provides some useful understanding into perceptions of preparers of financial reports among local governments in Nigeria, particularly during the on-going adoption of the cash-basis IPSAS.

\section{References}

Abbott, L. J., Daugherty, B., Parker, S., \& Peters, G. F. (2016). Internal audit quality and financial reporting quality: The joint importance of independence and competence. Journal of Accounting Research, 54(1), 3-40.

ACCA. (2017). IPSAS implementation: Current status and challenges. Retrieved from www.accaglobal.com

Achim, A. M. (2014). Financial accounting quality and Its defining characteristics. SEA - Practical Application of Science, II(3), 93-98.

Akhidime, A. (2012). Accountability and financial reporting in Nigeria public financial. Knowledge Review Volume, 26(3), 36-44.

Al-Tahat, S. S. Y. (2015). Company attributes and the timeliness of interim financial reporting in Jordan. International Journal of Application or Innovation in Engineering \& Management, 4(3), 6-16.

APEGGA. (2004). Concept of professionalism.

Armstrong, C. S., Guay, W. R., \& Weber, J. P. (2010). The role of information and financial reporting in corporate governance and debt contracting. Journal of Accounting and Economics, 50(2-3), 179-234.

Bageva, A. (2010). The quality of published accounting information in Russia. Issues in Accounting Education. https://doi. org/10.2308/iace.2002.17.4.411

Bakhtiar, M., \& Azimifar, M. (2013). The Impact of professional ethics on financial reporting quality. Advances in Environmental Biology, 7(10), 28622866.

Ball, R., Robin, A., \& Wu, J. S. (2003). Incentives versus standards: Properties of accounting income in four East Asian countries. Journal of Accounting and Economics, 36(1-3 SPEC. ISS.), 235270.

Barth, M. E., Beaver, W. H., \& Landsman, W. R. (2001). The relevance of the value relevance literature for financial accounting standard setting: Another view. Journal of Accounting and Economics, 31, 77-104.

Bartov, E., Goldberg, S. R., \& Kim, M. (2005). Comparative value relevance among German, U.S., and international accounting standards: A German stock marketperspective.JournalofAccounting, Auditing and Finance, 20(95). https:// doi.org/10.1177/0148558X0502000201

Bello-Imam, I. B. (2007). Local government finance in Nigeria (Second (Re). Ibadan: JODAD Publisher.

Braam, G., \& Beest, F. van. (2013). Conceptually-based financial reporting quality assessment an empirical analysis on quality differences between $U K$ annual reports and US 10-K reports.

Bukenya, M. (2014). Quality of accounting information and financial performance of Uganda's public sector. American Journal of Research Communication, 2(5), 183-203.

Burns, J., \& Scapens, R. W. (2000). Conceptualizing management accounting change: An institutional framework. 
Management Accounting Research, (November 1998), 3-25.

Bushman, R. M., \& Piotroski, J. D. (2006). Financial reporting incentives for conservative accounting: The influence of legal and political institutions. Journal of Accounting and Economics, 42, 107148 .

Chan, J. L. (1994). Accounting and financial management reform in the United States government: An application of professor Lüder's contingency model, 17-47.

Chan, J. L. (2008). International public sector accounting standards: Conceptual and institutional issues. The Harmonization of Government, 21, 1-15.

Chan, J. L., Jones, R. H., \& Lüder, K. G. (1996). Modeling governmental accounting innovations: An assessment and future research directions. Research in Government and Non-Profit Accounting, 9.

Chen, H., Tang, Q., Jiang, Y., \& Lin, Z. (2010). The role of international financial reporting standards in accounting quality: Evidence from the European Union. Journal of International Financial Management and Accounting, 21(3), 220-278. Retrieved from http://www. scopus.com/inward/record.url?eid=2s2.0-77955387234\&partnerID $=40 \& \mathrm{md} 5$ $=61 \mathrm{a} 5 \mathrm{c} 90 \mathrm{~b} 09 \mathrm{a} 30 \mathrm{afa} 804460 \mathrm{c} 66997 \mathrm{eca} 1$

Cheng, R. H., Engstrom, J. H., \& Kattelus, S. C. (2002). Educating government financial manager: University collaboration. The Journal of Government Financial Management, 51(3), 10-15.

Christiaens, J. (1999). Financial accounting reform in Flemish municipalities: An empirical investigation. European Accounting Review, 15(1), 803-804.

Cohen, S., Kaimenakis, N., \& Venieris, G. (2013). Reaping the benefits of two worlds An explanatory study of the cash and the accrual accounting information roles in local governments. Journal of Applied Accounting Research, 14(2), 165-179.
Cuong, N. T., \& Ly, D. T. (2017). Measuring and assessing the quality of iformation on the annual reports : The Case of seafood' s companies Listed on the Vietnam stock market. International Research Journal of Finance and Economics, 16(3).

Darwanis, D., Saputra, M., \& Kartini, K. (2016). Effect of professionalism, competence, knowledge of financial management, and intensity guidance apparatus inspectorate for quality of financial statements (study on inspectorate regencies / cities in Aceh ). Broad Research in Accounting, Negotiation and Distribution, 6(1), 3240.

Deans, S. (2007). Discussion of 'Is fair value accounting information relevant and reliable? Evidence from capital market research.' Accounting and Business Research, 37(sup1), 31-32. https://doi.or g/10.1080/00014788.2007.9730082

Dingle, J. (1995). Analysing the competence requirements of managers. Management Development Review, 8(2), 30-36. https:// doi.org/10.1108/09622519510082028

Dwyer, P. D., \& Wilson, E. R. (1989). An empirical investigation of factors affecting the timeliness of reporting by municipalities. Journal of Accounting and Public Policy, 8(1), 29-55. https:// doi.org/10.1016/0278-4254(89)90010-0

Emerole,O.B.,\&Enyioko, V.U.(2015). Nigerian union of local government employees and the struggle for wage control in Enugu state civil service. Journal of Business and Management, 17(2), 12-19. https:// doi.org/10.9790/487X-17241219

Espositi, G., Francesca, F., \& Bosco, V. (2015). Examining perception of competency through practicum competencies outline. European Journal of Training and Development, 39(8), 700-720.

Evetts, J. (2011). Professionalism as an occupational value: Theoretical challenges in the sociology of professions. Louvain Workshop Presentation. 
Evetts, J. (2013). Professionalism: Value and ideology. Current Sociology, 61(5-6), 778-796. https://doi. org/10.1177/0011392113479316

Falk, R. F., \& Miller, N. B. (1992). A primer for soft modeling.

Fornell, C., \& Larcker, D. (1981). Structural equation models with unobservable variables and measurement error: Algebra and statistics. Journal of Marketing Research, 18(3), 382-388.

Garuba, A. O., \& Donwa, P. (2011). The challenges of adopting international financial reporting system in Nigeria. JORIND, 1(9), 313-319.

Geisser, S. (1974). A predictive approach to the random effect model. Biometrika, 61(1), 101-107. https://doi.org/10.1093/ biomet/61.1.101

Giroux, G. (1989). Political interests and governmental accounting disclosure. Journal of Accounting and Public Policy, 8, 199-217.

Gjorgieva-Trajkovska, O., Koleva, B., \& Nikoloski, K. (2017). The importance of financial reporting for investment decision making. In Thirteenth International Scientific Conference. 25th - 28th May, 2017. Budva, Montenegro (p. 12).

Glomb, T. M., \& Liao, H. (2003). Interpersonal agression in work groups: Social influence, reciprocal, and individual effects. Academy of Management Journal, 46(4), 486-496.

Hair, J. F., Hult, G. T. M., Ringle, C. M., \& Sarstedt, M. (2014). A primer on partial least squares structural equation modelling (PLS-SEM).

Hair, J. F., Ringle, C. M., \& Sarstedt, M. (2011). PLS-SEM: Indeed a silver bullet. Journal of Marketing Theory and Practice, 19(2), 139-152.

Henseler, J., Ringle, C. M., \& Sinkovics, R. R. (2009). The use of partial least squares path modeling in international marketing. International Journal of Research in
Marketing, 20(4), 277-319. https://doi. org/10.1016/0167-8116(92)90003-4

Henseler, J., \& Chin, W. W. (2010). A comparison of approaches for the analysis of interaction effects between latent variables using partial least squares path modeling. Structural Equation Modeling, 17(1), 82-109. https://doi. org/10.1080/10705510903439003

Henseler, J., Hubona, G., \& Ray, P. A. (2016). Using PLS path modelling in new technology research: Updated guidelines using PLS path modelling in new technology research: Updated guidelines. Industrial Management \& Data Systems, (October 2015).

Henseler, J., Ringle, C. M., \& Sarstedt, M. (2015). A new criterion for assessing discriminant validity in variance-based structural equation modeling. Journal of the Academy of Marketing Science, 43(1), 115-135. https://doi.org/10.1007/ s11747-014-0403-8

Herath, K. S., \& Albarqi, N. (2017). Financial reporting quality: A literature review. International Journal of Business Management and Commerce, 2(2), 1-14.

Herbert, W. E., Ene, E. ., \& Tsegba, I. . (2014). Globalization of financial reporting : Obstacles to International Financial Reporting Standards ( IFRS ) adoption in Nigeria. Asian Journal of Business and Management Sciences, 3(12), 25-41.

Hirst, D. E., Hopkins, P. E., \& Wahlen, J. M. (2004). Fair values, income measurement, and bank analysts risk and valuation judgements. The Accounting Review, $79(2), 453-472$.

Hope, O. (2003). Disclosure practices, enforcement of accounting standards, and analysts' forecast accuracy: An international study. Journal of Accounting Researchesearch, 41(2), 235-272.

IASB. (2010). Conceptual framework for financial reporting. International Financial Reporting Standards (Vol. 87). https://doi.org/ISBN: 978-1-907026-690 Copyright 
IFAC. (2009). Financial reporting under the cash basis of accounting part 2: Encouraged additional disclosures.

IFAC International Federation of Accountants, \& IFAC. (2015). International Public Sector Accounting Standards Board Handbook of International Public Sector Accounting Pronouncements 2012 Edition (Vol. II).

Jonas, G. J., \& Blanchet, J. (2000). Assessing quality of financial reporting. American Accounting Association, Accounting Horizons, 14(3), 353-363.

Judge, W., Li, S., \& Pinsker, R. (2010). National adoption of international accounting standards: An institutional perspective. Corporate Governance, 18(3), 161-174.

Kak, N., Burkhalter, B., \& Cooper, M. (2001). Measuring the competence of healthcare providers. Quality Assurance, 2(1), 1-28.

Kasim, E. Y. (2015). Effect of government accountants competency and implementation of internal control to the quality of government financial reporting. International Journal of Business, Economics and Law., 8(1), 97-105.

Khumawala, S., Marlowe, J., \& Neely, D. (2014). Accounting professionalism and local government Gaap. Journal of Budgeting, Accounting \& Financial Management, 26(2), 292-312.

Kothari, C. R. (2004). Research methodology (Second Rev). New Delhi: New Age International Publisher.

Krejcie, R. V., \& Morgan, D. W. (1970). Determining sample size for research activities. Educational and Psychological Measurement, 30(3), 607-610.

Kura, K. M., Shamsudin, F. M., \& Chauhan, A. (2015). Does self-regulatory efficacy matter? effects of punishment certainty and punishment severity on organizational deviance. SAGE Open, 5(2). https://doi. org/10.1177/2158244015591822

Larcker, D. F., \& Lessig, V. P. (1980). Perceived usefulness of information: A psychometric examination. Decision Sciences, 11(1), 121-134.
Laswad, F., \& Redmayne, N. B. (2015). IPSAS or IFRS as the framework for public sector financial reporting? New Zealand preparers' perspectives. Australian Accounting Review, 25(2), 175-184. https://doi.org/10.1111/auar.12052

Lawshe, C. (1975). A quantitative approach to content. Personnel Psychology, 28, 563-575. https:// doi.org/10.1111/j.1744-6570.1975. tb01393.x

Legenzova, R. (2016). A concept of accounting quality from accounting harmonisation perspective. Journal of Economics and Business, 28(0005), 33-37.

Lin, Z., Jiang, Y., Tang, Q., \& He, X. (2015). Does high-quality financial reporting mitigate the negative impact of global financial crises on firm performance? Evidence from the United Kingdom does high-quality financial reporting mitigate the negative impact of. Australasian Accounting Business and Finance Journal, 8(5), 19-46.

Linsmeier, T. J. (2011). Financial reporting and financial crises: The case for measuring financial instruments at fair value in the financial statements. Accounting Horizons, 25(2), 409-417. https://doi. org/10.2308/acch-10024

Lüder, K. G. (1992). A contingency model of governmental accounting innovations in the political-administrative environment. Research in Government and Non-Profit Accounting, 7, 99-127.

Madawaki, A. (2014). Adoption of international financial reporting standards in developing countries: The case of Nigeria, 7(3), 152-161. https://doi. org/10.5539/ijbm.v7n3p152

Maigoshi, Z. S. (2014). The impact of mandatory adoption of international financial reporting standard on accounting quality in Nigeria.

Maines, L. A., \& Wahlen, J. M. (2006). The nature of accounting information reliability: Inferences from archival and experimental research. Accounting Horizons, 20(4), 399-425. 
Martínez-Ferrero, J., Garcia-Sanchez, I. M., \& Cuadrado-Ballesteros, B. (2013). Effect of financial reporting quality on sustainability information disclosure. Corporate Social Responsibility and Environmental Management, 22(1), 4564.

Massey, A. (1999). Quality issues in the public sector. Public Policy and Administration, 14(3).

Mataira, K., \& Van Peursem, K. A. (2010). An examination of disciplinary culture: Two professional accounting associations in New Zealand. Accounting Forum, 34(2), 109-122. https://doi.org/10.1016/j. accfor.2010.02.001

Mbobo, M. E., \& Ekpo, N. B. (2016). Operationalising the qualitative characteristics of financial reporting. International Journal of Finance and Accounting, 5(4), 184-192.

McDaniel, L., Martin, R. D., \& Maines, L. A. (2002). Evaluating financial reporting quality: The effects of financial expertise vs. financial literacy. Accounting Review, 77(SUPPLEMENT), 139-167.

Moehrle, S. R., Anderson, K. L., Ayres, F. L., Bolt-Lee, C. E., Debreceny, R. S., Dugan, M. T., ... Plummer, E. (2009). The impact of academic accounting research on professional practice: An analysis by the AAA research impact task force. Accounting Horizons, 23(4), 411-456. https://doi.org/10.2308/ acch.2009.23.4.411

Muñoz, L. A., Bolívar, M. P. R., \& Hernández, A. M. L. (2013). Financial determinants for improving public sector accountability: A meta-analytic study. Transylvanian Review of Administrative Sciences, (SPEC. ISSUE), 66-87.

Musa, A. (2015). International financial reporting standards and financial reporting quality among Nigerian listed companies. Othman Yeop Abdullah
Graduate School of Business, Universiti Utara Malaysia. https://doi.org/10.1017/ CBO9781107415324.004

Muzio, D., Brock, D. M., \& Suddaby, R. (2013). Professions and institutional change: Towards an institutionalist sociology of the professions. Journal OfManagement Studies, 50(July). https://doi.org/10.1111/ joms. 12030

Ninlaphay, S., \& Ussahawanitchakit, P. (2011). Accounting professionalism, financial reporting quality and information usefulness: Evidence from exporting firms in Thailand. Journal of International Business and Economics, 11(4), 155-167.

Nobe, A. A. (2015). Reforming public sector accounting and financial systems: A critique of Cameroon and Nigeria. International Journal of Accounting \& Business Finance, (I), 86-101.

Nur Afiah, N., \& Rahmatika, D. N. (2014). Factors influencing the quality of financial reporting and its implications on good government governance (research on local government Indonesia). International Journal of Business, Economics and Law, 5(1), 111-121.

Okereke, C. I., \& Daniel, A. (2010). Staff welfare and productivity in Patani local government council, Delta State Nigeria. Ournal of Economics and International Finance, 2(December), 313-320.

Okey, O., \& Okechukwu, E. (2013). The general rules and principles of patrolling in Nigerian local government system - Singaporean Journal of Business Economics, and Management Studies, 1(1), 54-59.

Onyishi, A. O., Eme, O. I., \& Emeh, I. E. J. (2012). Problems of personnel management in Nigeria: The Nigerian local government system experience. Arabian Journal of Business and Management Review (OMAN Chapter Arabian Journal of 
Business and Management Review (OMAN Chapter), 1(16), 36-49. Retrieved from https://www.arabianjbmr. com/pdfs/OM_VOL_1_(6)/3.pdf

Pina, V., Torres, L., \& Royo, S. (2010). Is e-government leading to more accountable and transparent local governments? An overall view. Financial Accountability \& Management, 26(1), 3-20. https://doi.org/10.1111/j.14680408.2009.00488.x

Podsakoff, P. M., \& Organ, D. W. (1986). Self-reports in organizational research: Problems and prospects. Journal of Management 1986, 12(4), 531. https:// doi.org/10.1177/014920638601200408

Puncreobutr, V., Chumark, C., \& Tipajatuporn, K. (2017). Correlation between accountants' competence and the quality of financial reports of SMEs in the Province of Nakorn Nayok. SSRN: Https://Ssrn.Com/ Abstract $=2908676$ or Http://Dx.Doi. Org/10.2139/Ssrn.2908676, 1-9.

Robbins, W. A., \& Austin, K. R. (1986). Disclosure quality in governmental financial reports: An assessment of the appropriateness of a compound measure. Journal of Accounting Research, 24(2), 412-421.

Rutherford, B. A. (1992). Developing a conceptual framework for central government financial reporting: Intermediate users and indirect control. Financial Accountability \& Management, 8(4), 265-280. https:// doi.org/10.1111/j.1468-0408.1992. tb00443.x

Saputra, M., \& Hutahaean, S. M. M. (2016). The effect of financial management knowledge, competence and supervision act of the government's internal control officer on the quality of government's performance accountability report evaluation. Academic Journal of Economic Studies, 2(2), 20-31.

Setiyawati, H. (2013). The effect of internal accountants' competence, managers' commitment to organizations and the implementation of the internal control system on the quality of financial reporting. International Journal of Business and Management Invention, 2(11), 19-27.

Staubus, G. J. (2004). On Brian P. West's professionalism and accounting rules. Abacus, 40(2), 139-156. https://doi. org/10.1111/j.1467-6281.2004.00155.x

Ştefănescu, A. (2013). Dissemination of financial information into the public sector - An approach from the view of the central public administration entities from Romania. Annales Universitatis Apulensis-Series Oeconomica, 15(1), 134-144.

Svensson, L. G. (2006). New professionalism, trust and competence: Some conceptual remarks and empirical data. Current Sociology, 54(4), 579. https://doi. org/10.1177/0011392106065089

Tarus, M. J., Muturi, D., \& Kwasira, J. (2015). Determinants of accurate financial statements reporting in listed banks in Kenya; A survey of commercial banks in Nakuru Town. Journal of Business and Management, 17(4), 79-86.

Upping, P., \& Oliver, J. (2011). International review of business research papers accounting change model for the public sector: Adapting Luder's model for developing countries. International Review of Business Research Papers, 7(1), 364-380.

Van Tendeloo, B., \& Vanstraelen, A. (2005). Earnings management under German GAAP versus IFRS. European Accounting Review, 14(1), 155-180.

Willaby, H. W., Costa, D. S. J., Burns, B. D., MacCann, C., \& Roberts, R. D. (2015). Testing complex models with small sample sizes: A historical overview and empirical demonstration of what Partial 
Least Squares (PLS) can offer differential psychology. Personality and Individual Differences, 84, 73-78. https://doi. org/10.1016/j.paid.2014.09.008

Xu, H., Nord, J. H., Nord, G. D., \& Lin, B. (2003). Key issues of accounting information quality management an Australian case study. Industrial Management \& Data Systems, 103(7), 461-470.

Zimmerman, J. L. (1977). Discussion of the municipal accounting maze: An analysis of political incentives. Journal of Accounting Research, 15(1977), 107144. 